\title{
EVALUATION OF Metarhizium anisopliae var. anisopliae Qu-M845 ISOLATE TO CONTROL Varroa destructor (Acari: Varroidae) IN LABORATORY AND FIELD TRIALS
}

\author{
Marta Rodríguez ${ }^{1}$, Marcos Gerding ${ }^{1 *}$, Andrés France ${ }^{1}$, and Ricardo Ceballos ${ }^{1}$
}

\begin{abstract}
The effectiveness of the Metarhizium anisopliae (Metschinkoff) Qu-M845 isolate was evaluated in laboratory and field trials. It was previously selected for thermal resistance (at 30 and $35^{\circ} \mathrm{C}$ ) and pathogenicity on Varroa destructor (Anderson and Trueman). In the laboratory, the first evaluations were carried out by spraying and increasing the concentration from zero to $10^{8}$ conidia $\mathrm{mL}^{-1}$ on varroa adults. Lethal concentrations required for 50 and $90 \%$ mite mortality $\left(\mathrm{LC}_{50}\right.$ and $\left.\mathrm{LC}_{90}\right)$ were $3.8 \times 10^{5}$ and $8 \times 10^{7}$ conidia $\mathrm{mL}^{-1}$, respectively $\left(\chi^{2}=2.03\right)$. In the autumn field trials, three application methods (doses of $5 \times 10^{10}$ conidia per hive) were evaluated. The treatments were: a) conidia stamped on filter paper, located on every second frame inside the hive; b) dry conidia sprinkled on and between frames; and c) dry conidia in a dispenser path at the entrance of the hive. Furthermore, untreated hives were included as controls. After 21 days of treatment, the dry conidia sprinkled on and between frames showed $67 \%$ less bees infested by the mite than the control $(\mathrm{p}<0.05)$. Average bee mortality observed was significantly different between treatments $(\mathrm{p}<$ 0.05). The sprinkled dry conidia caused the highest mortality of bees. In spring, this treatment produced increased mite mortality and without bee mortality. These results demonstrated that it is possible to develop a biological insecticide based on this isolate to generate an alternative to control V. destructor.
\end{abstract}

Key words: biological control, entomopathogenic fungi, Varroa destructor, varroasis, insect pathology, Metarhizium anisopliae.

\section{INTRODUCTION}

The Varroa destructor (Acari: Varroidae) mite is originally from Asia where it parasitizes bees Apis cerana Fabr. (Hymenoptera: Apidae). Due to seasonal migration of livestock, this parasite was extended to Apis mellifera Linnaeus, causing serious worldwide damage to the population of this species (Chandler et al., 2001). Since its detection in Chile in 1992, in the Province of San Fernando, Libertador General Bernardo O'Higgins Region, it has spread to almost the whole country causing serious economic losses to beekeepers (Hinojosa and González, 2004; Neira et al., 2004).

Varroasis, the disease caused by this mite, starts when the fertilized $V$. destructor female abandons the adult bee that it has parasitized and penetrates in a bee breeding cell about to be sealed. Mite oviposition starts two days later, the female lays between 3 and 12 eggs, after $48 \mathrm{~h}$ the nymphs

'Instituto de Investigaciones Agropecuarias INIA, Casilla 426, Chillán, Chile. "Corresponding author (mgerding@inia.cl).

Received: 02 November 2007.

Accepted: 07 April 2008. are born, start to feed on the hemolymph of the forming bee, and are converted into adults within 5 to 8 days. The mating of the mites occurs in the cell before the bee emerges (Harbo and Harris, 1999; Llorente, 2003).

The $V$. destructor female looks for the soft zones of the adult bees to perforate and suck their hemolymph, causing physical damage by decreasing protein content, and infectious toxin due to the transmission of microorganisms causing viral and bacterial diseases (Chandler et al., 2001; Nordström, 2003).

Methods to control varroasis are based on the use of synthetic acaricides such as tau-fluvalinate, flumetrin, and coumaphos. However, it is possible to find resistance to these products (Harbo and Harris, 1999) and their residues in honey and wax (Calderone, 1999; Pérez et al., 2000). Another alternative control is the use of oils and organic acids such as formic acid, oxalic acid, and thymol, which have been intensively studied in Europe and Asia. In spite of its effectiveness in controlling varroa, damaging effects have been reported on bees, such as alteration in the recognition of the queen's oviposition, bee mortality, and caustic effects on the skin of the handler (Calderone, 1999; Kanga et al., 2003; Floris et al., 2004). 
An alternative control method is the use of biological control agents, a practice which has aroused increasing interest, given the concern to count on new noncontaminating ways of pest control, and because more is known about the biology and controlled production of these entomopathogenic organisms (Tanada and Kaya, 1993; Dorta and Arcas, 1996). Background information on the use of entomopathogenic fungi (EPF) point out that it is possible to control mites in all of their stages, including eggs, with fungi such as Beauveria bassiana (Balsamo) Vuillemin and Metarhizium anisopliae var. anisopliae (Metschinkoff) (Chandler et al., 2000). Field trials carried out in beehives in the U.S. have demonstrated the capacity of M. anisopliae to control V. destructor (Kanga et al., 2003).

Preliminary trials carried out by the Centro Tecnológico de Control Biológico of the Instituto de Investigaciones Agropecuarias INIA Quilamapu with entomopathogenic fungi has made it possible to obtain the M. anisopliae $\mathrm{Qu}-$ M845 isolate, selected for its thermal tolerance and high pathogenicity on V. destructor (Rodriguez et al., 2009). In accordance with the above-mentioned, the purpose of this study was to evaluate the mortality caused by this isolate on Varroa destructor, determine the lethal concentration (LC) and the lethal time (LT) for the concentration close to $\mathrm{CL}_{90}$ in laboratory conditions, as well as to study different application methods and effectiveness in the field.

\section{MATERIALS AND METHODS}

\section{Laboratory trials}

Trials were carried out in the laboratories of the Centro Tecnológico de Control Biológico of the Instituto de Investigaciones Agropecuarias INIA, Centro Regional de Investigación Quilamapu and in the apiary of the Campo Experimental Santa Rosa, Chillán, Chile.

\section{Isolate multiplication}

We used a strain of $M$. anisopliae var. anisopliae $\mathrm{Qu}-$ M845 sown on Petri dishes with potato dextrose agar (PDA) and incubated at $25^{\circ} \mathrm{C}$ until sporulation. Conidia were harvested from the surface of the culture carried out in a sterile distilled water suspension plus $0.1 \%$. Tween 80 (Sigma ${ }^{\circledR}$, Steinheim, Germany). Conidia concentration was determined with a Neubauer counting chamber (BOECO, Germany) (Rodríguez et al., 2006).

\section{Lethal concentration test}

Female $V$. destructor adults were collected from infested beehives and transferred to plastic chambers with blotting paper at the bottom. Then suspensions were applied: $10^{5}, 10^{6}, 10^{7}$, and $10^{8}$ conidia $\mathrm{mL}^{-1}$, plus Tween 80 on $V$. destructor adults, with a Potter pulverization tower system. Adults treated with distilled water plus Tween 80 made up the control. Inoculated varroa were immediately placed on drone pupas maintained in $1 \mathrm{~mL}$ plastic tubes with cotton wool at the top and incubated between 25 and $30{ }^{\circ} \mathrm{C}$ in the dark (Rodríguez et al., 2009).

Varroa mortality with the different inoculum concentrations were recorded daily and the dead mites were incubated in humid chambers at $25{ }^{\circ} \mathrm{C}$ to observe symptoms of mycosis. Microscopic preparations were carried out with the dead bodies to identify the fungus and check if it coincided with the initial isolate. The experimental design was completely random with five treatments and five replicates, each experimental unit consisting of 10 mites. Varroa mortality curves were expressed as a percentage of mortality in distinct concentrations and were adjusted to sigmoid curves from which $\mathrm{CL}_{50}$ and $\mathrm{CL}_{90}$ were calculated. Mortality of distinct concentrations were compared on day 7 post inoculation with analysis of variance and mean separation by the Tukey test ( $\mathrm{p}<0.05)$ (Gomez and Gomez, 1984). TL $\mathrm{L}_{50}$ was calculated from the mortality observations accumulated over time with $\mathrm{CL}_{90}$.

\section{Field trials}

\section{Evaluation of application methods}

An apiary, with 25 Langstroth-type hives of $A$. mellifera, was established in the Campo Experimental Santa Rosa (36 $31^{\prime}$ S, $71^{\circ} 54^{\prime}$ W) of INIA-Quilamapu in October 2005. In May 2006, doses of 5 x $10^{10}$ conidia (10\% humidity) were prepared for each hive from the $M$. anisopliae Qu-M845 isolate obtained from precooked sterile rice. Treatments consisted in three application methods: a) conidia stamped on filter paper located on every second moveable frame inside the hive; b) conidia sprinkled on and between the frames; and c) conidia dispenser path located at the one way entrance of the hives. Furthermore, a control treatment was included that consisted in hives without any treatment. Sampling was carried out before the trial to determine the initial percentage of varroa infestation.

The experimental design was completely randomized with four treatments and three replicates. The experimental unit was one beehive. Evaluation of bee and varroa mortality after the fungus application was carried out with an open cardboard with Vaseline that was placed on the floor of each hive and evaluated every $48 \mathrm{~h}$ over a period of $15 \mathrm{~d}$. The individuals collected were incubated in a humid chamber to detect signs of mycosis. Results of mortality over time were adjusted to sigmoid curves and comparison of cumulative mortality means on day 15 post inoculation by Fisher's protected test $(\mathrm{p}<0.05)$. After 21 d post-treatment, beehives were evaluated to determine $V$. destructor infestation levels and 200 bees were collected from each hive and placed in a jar with water 
and detergent. They were subsequently shaken to separate the varroa from the bodies of the bees and the number of mites per bee was counted (SAG, 2002). Results were compared among treatments to identify the percentage of parasitized bees and the relationships between the final and initial populations (Pf/Pi), both submitted to analysis of variance and mean separation by the Tukey test $(\mathrm{p}<$ $0.05)$.

\section{Spring evaluation}

During the spring, four M. anisopliae (Qu-M845) applications were carried out every $4 \mathrm{~d}$ between September 1 and 16, and afterwards, another four between October 16 and 31 . All the doses were $5 \times 10^{10}$ conidia per hive, applied between the frames of the breeding chamber. The control was beehives without any applications. Following the methodology described above, the effect of the fungus on the bees and mites during $12 \mathrm{~d}$ was evaluated by taking out a cardboard with Vaseline every $48 \mathrm{~h}$.

The experimental design was completely random with a beehive as an experimental unit, two treatments, and five replicates. The varroa and bee mortality curves for each inoculated hive were calculated twice: at the start of spring and $45 \mathrm{~d}$ later, and results were expressed as mortality over time by adjusting sigmoid curves. Cumulative mortality was compared on day 15 post inoculation with analysis of variance and mean separation with Fisher's protected test ( $\mathrm{p}<0.05)$ (Gomez and Gomez, 1984).

\section{RESULTS AND DISCUSSION}

\section{Laboratory trials}

The mites that died with the EPF treatment were incubated in humid chambers and showed symptoms of mycosis of the inoculated fungus, which was demonstrated by the presence of mycelium and spores in the legs and abdomen, whereas the control treatment showed no symptoms.

The $M$. anisopliae Qu-M845 isolate produced 98\% varroa mortality on day 7 post inoculation with a concentration of $10^{8}$ conidia $\mathrm{mL}^{-1}$. The treatment with $10^{7}$ conidia $\mathrm{mL}^{-1}$ produced a different value, $72 \%$ mortality. The $10^{6}$ and $10^{5}$ conidia $\mathrm{mL}^{-1}$ concentrations the varroa mortality were similar, 46 and $48 \%$, respectively ( $\leq \leq 0.05)$. During this period, mortality did not occur in the $V$. destructor control (Figure 1). $\mathrm{CL}_{50}$ and $\mathrm{CL}_{90}$, with $3.8 \times 10^{5}$ and $8 \times 10^{7}$ conidia $\mathrm{mL}^{-1}$, respectively $\left(\chi^{2}=2.03\right)$ were obtained from the sigmoid formula (Table 1).

Kanga et al. (2002) obtained $\mathrm{CL}_{90}$ for $V$. destructor of $1.37 \times 10^{9}$ conidia $\mathrm{mL}^{-1}$ of an M. anisopliae isolate on day 7 post inoculation, which was higher than that obtained in this trial. For other mite species like Tetranychus evansi, Wekesa et al. (2005) point out a lethal concentration between $0.7 \mathrm{x}$
$10^{7}$ and $2.3 \times 10^{7}$ conidia $\mathrm{mL}^{-1}$ to achieve the $50 \%$ mortality with diverse $M$. anisopliae isolates, values that are again higher than those found in our trials.

Lethal time to kill $50 \%$ of the population $\left(\mathrm{TL}_{50}\right)$ was calculated with the $1 \times 10^{7}$ concentration, value corresponding to the closest calculation of $\mathrm{CL}_{90}$. Results indicated $\mathrm{TL}_{50}$ of $1.35 \mathrm{~d}$. Meikle et al. (2006) observed a lethal time of 4 to $7 \mathrm{~d}$ for varroa with a dose of $10^{7}$ conidia $\mathrm{mL}^{-1}$ of $M$. anisopliae with an inoculation technique and maintenance of the mites similar to the one described. These values were higher than those that we found. Chandler $e t a l$. (2000) point out that death of the entomopathogenic fungi generally occurs in a period of 3 to $10 \mathrm{~d}$ after the infection, which is produced by water loss, nutrient deprivation, mechanical damage, and toxin action.

\section{Evaluation of application methods}

After the applications, treatments with fungi presented a $V$. destructor infestation significantly different and lower than the control. The treatment with conidia sprinkled on the frames presented a $67 \%$ decrease in the percentage of infested bees with respect to the mite population in the control (Figure 2A). Concerning to the variation of the populations $(\mathrm{Pf} / \mathrm{Pi})$, the control increased 1.7 times the initial population, treatments with stamped conidia and conidia dispenser maintained a relationship close to one which indicates that the varroa population did not grow. Lastly, the treatment with sprinkled conidia decreased 0.72 times the initial population (Figure 2B). Cumulative mite mortality during this period showed similar results when directly applying the conidia on and between the frames,

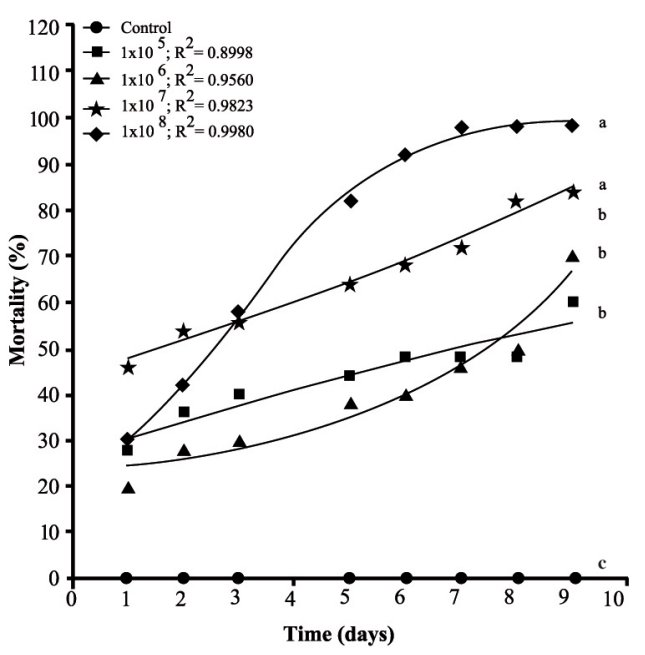

Distinct letters indicate significant differences according to Tukey test $(\mathrm{p}<0.05)$.

Figure 1. Mortality of Varroa destructor inoculated with different concentrations of Metarhizium anisopliae var. anisopliae $\mathrm{Qu}-\mathrm{M845}$ isolate. 
Table 1. Determination of lethal concentration $50\left(\mathrm{LC}_{50}\right)$ and $90\left(\mathrm{LC}_{90}\right)$ of Metarhizium anisopliae var. anisopliae to control Varroa destructor 7 days after being inoculated with different concentrations of Qu-M845 isolate.

\begin{tabular}{|c|c|c|c|c|c|c|c|c|c|}
\hline \multirow[b]{2}{*}{ Isolate } & \multirow[b]{2}{*}{ Slope } & \multirow[b]{2}{*}{ Intersection } & \multirow[b]{2}{*}{$X^{2}$} & \multirow[b]{2}{*}{$\mathrm{CL}_{50}$} & \multicolumn{2}{|c|}{ IC $95 \% \mathrm{CL}_{50}$} & \multirow[b]{2}{*}{$\mathrm{CL}_{90}$} & \multicolumn{2}{|c|}{ IC $95 \% \mathrm{CL}_{90}{ }^{1}$} \\
\hline & & & & & L inf. & L sup. & & L inf. & L sup. \\
\hline Qu-M845 & 0.55 & -3.09 & 2.03 & $3.8 \times 10^{5}$ & $1.4 \times 10^{3}$ & $2.4 \times 10^{6}$ & $8 \times 10^{7}$ & $9.3 \times 10^{6}$ & $7.8 \times 10^{12}$ \\
\hline
\end{tabular}

${ }^{1}$ Interval with $95 \%$ confidence.

and the conidia adhered to filter paper, but were statistically different to the results obtained with the other treatments ( $\mathrm{p}$ $=0.0093$ ) (Figure 3). Despite these results, an infestation level less than or equal to $3 \%$ was not obtained, level recommended as tolerable in the hive (Neira et al., 2004). However, these results were obtained at $21 \mathrm{~d}$, and could be expected to continue decreasing as the Metarhizium inoculant managed to multiply itself in the dead varroa.

Kanga et al. (2006) obtained similar results when evaluating plastic strips covered with $M$. anisopliae spores to control V. destructor in bee colonies in autumn.

When evaluating cumulative bee mortality for each treatment, differences in the death of bees over time were observed, hives in which conidia were applied on and between the frames had greater bee mortality than the rest
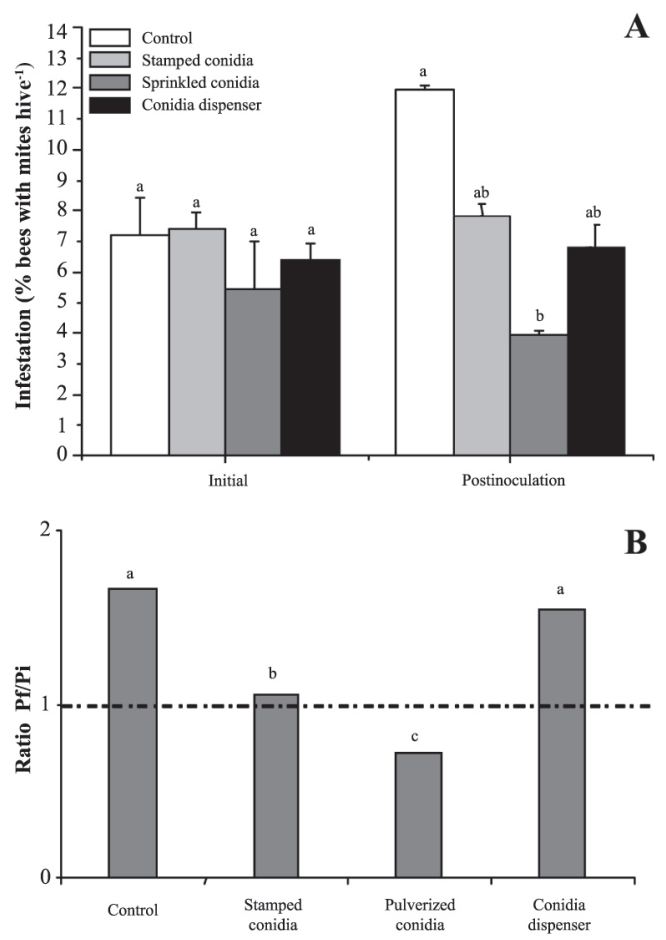

Distinct letters for each period indicate significant differences according to Tukey test $(\mathrm{p}<0.05)$.

Figure 2. A) Level of Varroa destructor infestation in honey bee colonies before and after treatment with Metarhizium anisopliae var. anisopliae, Qu-M845 isolate. B) Ratio of final and initial populations of mites. of the treatments; furthermore, they were similar $(\mathrm{p}<0.05)$ to the control beehives (Figure 4). Out of 154 dead bees in the hives treated with conidia sprinkled on the frames, $35 \%$ showed mycosis. Though it has been reported that $M$. anisopliae can infect A. mellifera in laboratory trials, at this time, it has not been reported to cause epizootics between bees (Chandler et al., 2001). More recently, Metarhizium has been considered for controlling other bee pests such as the Aethina tumida (Coleoptera: Nitidulidae) parasite in South Africa from isolated strains from this insect (Muerrle et al., 2006). Gliñski and Buczek (2003) point out that the hard, waterproof cuticle, biochemical activity of the juice of the middle intestine, and its peritrophic membranes, along with the tracheal system form a physiological mechanism and barriers that effectively protect the cavity of the body against invasion by fungi in bees. Furthermore, the antimicrobial substances such as phytocides (volatile organic alelochemical antimicrobial compounds), and volatile essences present in the ingested food can also destroy bacteria and invasive fungi. However, the infections with high spore doses or infections caused by highly pathogenic fungi species can destroy the anatomy and physiology of these immunological barriers Gliñski and Buczek (2003).

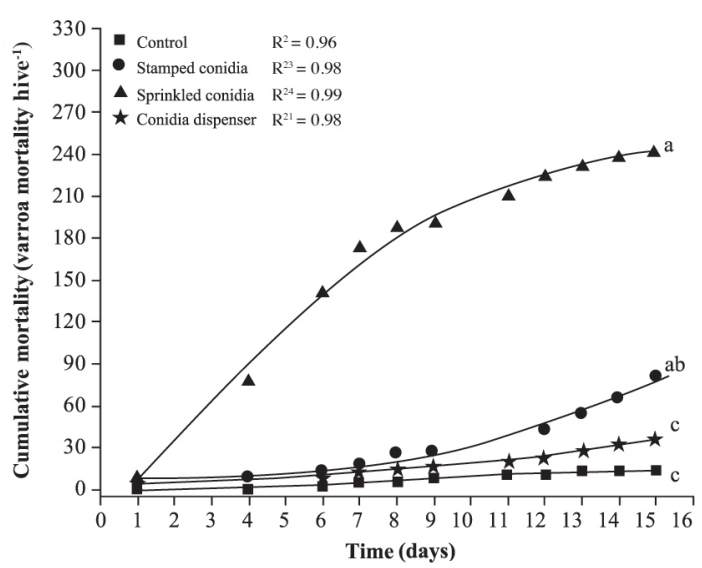

Distinct letters indicate significant differences according to Fisher's protected test $(\mathrm{p} \leq 0.05)$.

Figure 3. Cumulative mortality of Varroa destructor over time with different application methods of Metarhizium anisopliae var. anisopliae Qu-M845 isolate. 


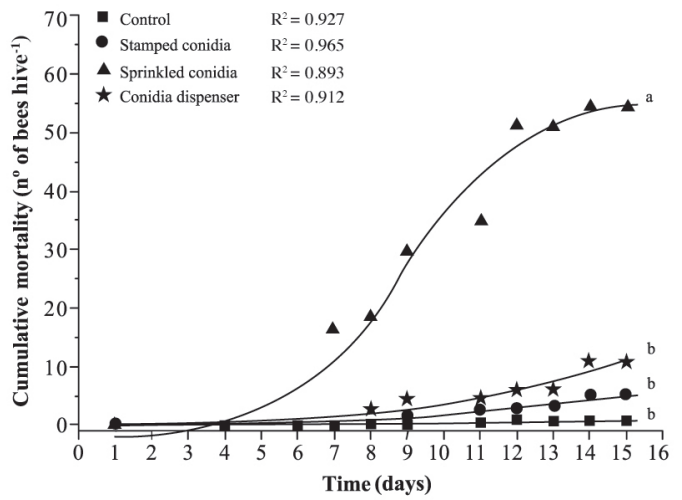

*Distinct letters indicate significant differences according to Fisher's protected test $(\mathrm{p} \leq 0.05)$.

Figure 4. Cumulative mortality of honey bees over time with different application methods of Metarhizium anisopliae var. anisopliae $\mathrm{Qu}-\mathrm{M845}$ isolate.

On the average, in the control beehives, 71 dead bees were recorded, but only $1.5 \%$ presented parasitism by Metarhizium. This can be explained by the transport of the conidia by the wind when they were applied, by drones taking the conidia from one hive to another, or by bees drifting between hives (Kanga et al., 2003), as well as for the proximity between treatments. Indeed, Meikle et al. (2007) found that the percentage of varroa infected with $B$. bassiana also increased in the control, suggesting conidia movement probably due to drifting bees. Kanga et al. (2003) indicate that conidia can be easily applied in an apiary, factor that can be beneficial for beekeepers. In accordance with this, and to the results obtained, it is concluded that the most effective application method is the pulverization of conidia on the frames.

\section{Spring evaluation}

When evaluating the effect of the fungus on the beehives in spring, significant differences were observed between the hives treated with the Qu-M845 isolate and the control hives (Figure 5). The mite mortality curve over time was adjusted to a sigmoid for both evaluation dates. On the two dates, the hives treated with fungi produced greater mite mortality $\left(\mathrm{R}^{2}=0.98\right.$ and $\left.\mathrm{R}^{2}=0.95\right)$ for the first and second observation date, respectively. The percentage differences between treated and untreated hives was 87 and $52.4 \%$ (Figure $5 \mathrm{~A}$ and $\mathrm{B}$ ).

These results concur with those obtained by Meikle $e t$ al. (2007), who observed an increase in the percentage of infected mites in the hives treated with a B. bassiana isolate. No significant differences were observed in bee mortality among treatments for both application dates (September and October) $(\mathrm{p} \leq 0.05)$ (Figure 6A and 6B). Neither were symptoms of mycosis observed in the collected bees, ruling out mortality caused by fungus. The lack of pathogenesis

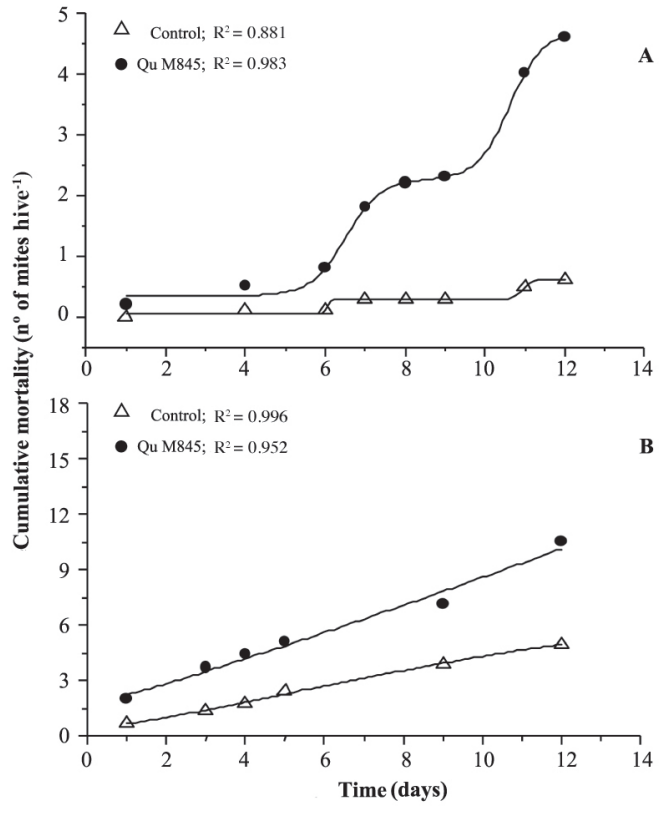

Figure 5. Cumulative mortality of Varroa destructor over time in hives, after the first day of treatment with Metarhizium anisopliae var. anisopliae $\mathrm{Qu}-\mathrm{M845}$ isolate application. A) Applied on September 5, 8, 12, and 16. B) Applied on October 19, 23, 27, and 31.

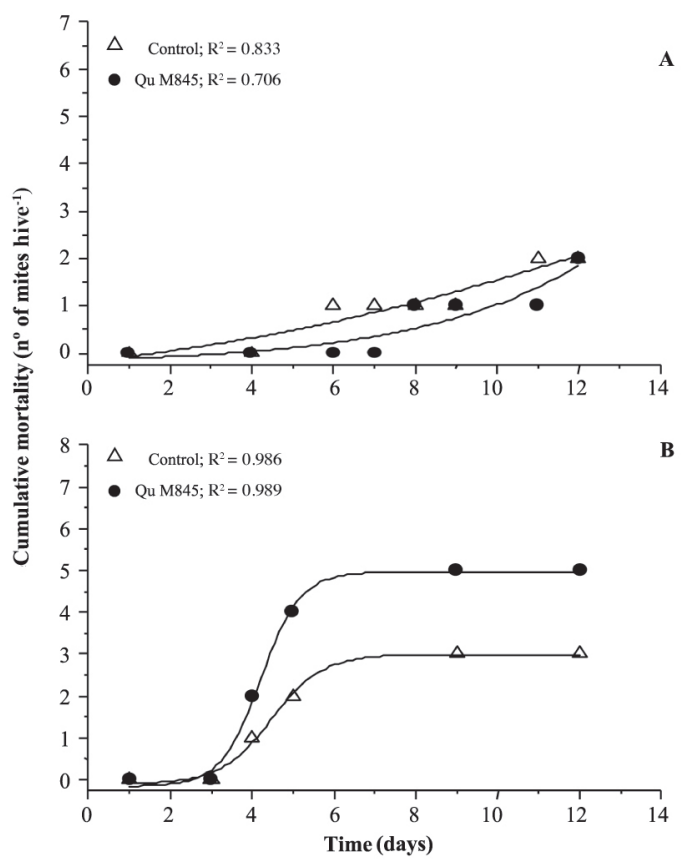

Figure 6. Cumulative mortality of honey bees over time in hives, after the first day of treatment with Metarhizium anisopliae var. anisopliae $\mathrm{Qu}-\mathrm{M845}$ isolate application. A) Applied on September 5, 8, 12, and 16. B) Applied on October 19, 23, 27, and 31. 
of $M$. anisopliae for other animals, including mammals, as well as the results obtained, indicate that this species is a promising alternative for the biological control of varroa. However, before recommending its use as a biological control agent of $V$. destructor or of other bee pests, more field evaluations are necessary to define the effects on beehives (Muerrle et al., 2006).

\section{CONCLUSIONS}

In laboratory conditions, the Metarhizium anisopliae var. anisopliae Qu-M845 native isolate was pathogenic for Varroa destructor. The values of the lethal concentrations were lower than in other studies. Conidia pulverized on and between the frames at a dose 600 times greater than $\mathrm{CL}_{90}$ considerably reduced mite infestation in autumn and spring. These results lead us to consider M. anisopliae as a promising tool to control $V$. destructor.

\section{ACKNOWLEDGEMENTS}

The authors thank Sady Muena for his valuable collaboration in developing this research.

\section{RESUMEN}

Evaluación del aislamiento Qu-M845 de Metarhizium anisopliae var. anisopliae para el control de Varroa destructor (Acari: Varroidae) en ensayos de laboratorio y terreno. La efectividad del aislamiento Qu-M845 de Metarhizium anisopliae (Metschinkoff), seleccionado previamente por su resistencia a temperaturas de 30 y 35 ${ }^{\circ} \mathrm{C}$, y patogenicidad sobre Varroa destructor Anderson y Trueman fue evaluada en laboratorio y en ensayos de terreno. Las primeras pruebas consistieron en pulverizar concentraciones crecientes de 0 a $10^{8}$ conidias $\mathrm{mL}^{-1}$ sobre varroas adultas. La concentración letal para matar el 50 y $90 \%$ de la población $\left(\mathrm{CL}_{50}\right.$ y $\left.\mathrm{CL}_{90}\right)$ fueron de $3,8 \times 10^{5}$ y $8 \times 10^{7}$ conidias $\mathrm{mL}^{-1}$, respectivamente $\left(\chi^{2}=\right.$ $2,03)$. En otoño se evaluaron en terreno tres métodos de aplicación de una dosis de $5 \times 10^{10}$ conidias por colmena Los tratamientos fueron: a) conidias estampadas en papel filtro ubicado cada dos panales móviles al interior de la colmena; b) conidias espolvoreadas sobre y entre los panales; y c) dispensador de conidias ubicado en la piquera de las colmenas. Además se incluyeron colmenas sin tratar (testigo). Después de 21 días de la aplicación, el tratamiento de conidias espolvoreadas sobre y entre los panales presentó una disminución de $67 \%$ en el porcentaje de abejas infestadas, en relación al testigo $(\mathrm{p}<0,05)$. Al evaluar la mortalidad de abejas se observaron diferencias entre tratamientos, siendo el espolvoreo de conidias el que causó mayor caída de abejas $(\mathrm{p}<0,05)$. En primavera, este tratamiento produjo un aumento en la caída de ácaros sin registrar mortalidad de abejas. Estos resultados indican que es factible desarrollar un acaricida biológico en base a este aislamiento, generando, con ello, una alternativa de control para V. destructor.

Palabras clave: control biológico, hongo entomopatógeno, Varroa destructor, varroasis, Metarhizium anisopliae.

\section{LITERATURE CITED}

Calderone, N. 1999. Evaluation of formic acid and a thymolbased blend of natural products for the fall control of Varroa jacobsoni (Acari: Varroidae) in colonies of Apis mellifera (Hymenoptera: Apidae). J. Econ. Entomol. 92:253-260.

Chandler, D., G. Dadidson, J. Pell, B. Vall, K. Shaw, and K. Sunderland. 2000. Fungal biocontrol of acari. Biocontrol Sci. Technol. 10:357-384.

Chandler, D., K.D. Sunderland, B.V. Ball, and G. Davison. 2001. Prospective biological control agents of Varroa destructor n. sp., an important pest of the European honeybee, Apis mellifera. Biocontrol Sci. Technol. 11:429-448.

Dorta, B., y A. Arcas. 1996. Producción de hongos entomopatógenos. p. 195-206. In Lecuona, R. (ed.) Microorganismos patógenos empleados en el control microbiano de insectos plagas. Talleres Gráficos Mariano Mas, Buenos Aires, Argentina.

Floris, I., A. Satta, P. Cabras, V. Garau, and A. Angioni. 2004. Comparison between two thymol formulations in the control of Varroa destructor: effectiveness, persistence, and residues. J. Econ. Entomol. 97:187191.

Gliñski, Z., and K. Buczek. 2003. Response of the Apoidea to fungal infections. Apiacta 38:183-189.

Gomez, K., and A. Gomez. 1984. Statistical procedures for agricultural research. $2^{\text {nd }}$ ed. John Wiley \& Sons, Singapore.

Harbo, J., and J. Harris. 1999. Heritability in honey bees (Hymenoptera: Apidae) of characteristics associated with resistance to Varroa jacobsoni (Mesostigmata: Varroidae). J. Econ. Entomol. 92:261-265.

Hinojosa, A., y D. González. 2004. Prevalencia de parásitos en Apis mellifera L. en colmenares del secano costero e interior de la VI Región, Chile. Parasitol. Latinoam. 59:137-141.

Kanga, L.H., R.R. James, and D.G. Boucias. 2002. Hirsutella thompsonii and Metarhizium anisopliae as potential microbial control agents of Varroa destructor, a honey bee parasite. J. Invertebr. Pathol. 81:175-84. 
Kanga, L.H, W.A. Jones, and C. Gracia. 2006. Efficacy of strips coated with Metarhizium anisopliae for control of Varroa destructor (Acari: Varroidae) in honey bee colonies in Texas and Florida. Exp. Appl. Acarol. 40:249-58.

Kanga, L.H., W. Jones, and R. James. 2003. Field trials using the fungal pathogen, Metarhizium anisopliae (Deuteromycetes: Hyphomycetes) to control the ectoparasitic mite, Varroa destructor (Acari: Varroidae) in honey bee, Apis mellifera (Hymenoptera: Apidae) colonies. J. Econ. Entomol. 96:1091-1099.

Llorente, J. 2003. Principales enfermedades de las abejas. 158 p. Subdirección General de Sanidad Animal, Ministerio de Agricultura Pesca y Alimentación, Madrid, España.

Meikle, W.G., G. Mercadier, V. Girod, F. Derouné, and W.A. Jones. 2006. Evaluation of Beauveria bassiana (Balsamo) Vuillemin (Deuteromycota: Hyphomycetes) strains isolated from varroa mites in southern France. J. Apicultural Res. 45:219-220.

Meikle, W.G., G. Mercadier, N. Holst, C. Nansen, and V. Girod. 2007. Duration and spread of an entomopathogenic fungus, Beauveria bassiana (Deuteromycota: Hyphomycetes), used to treat varroa mites (Acari: Varroidae) in honey bee (Hymenoptera: Apidae) hives. J. Econ. Entomol. 100:1-10.

Muerrle, T.M., P. Neumann, J.F. Dames, H.R. Hepburn, and M.P. Hill. 2006. Susceptibility of adult Aethina tumida (Coleoptera: Nitulidae) to entomopathogenic fungi. J. Econ. Entomol. 99:1-6.

Neira, M.,P.Heinsohn, R. Carrillo, A. Báez, y J. Fuentealba. 2004. Efecto de aceites esenciales de lavanda y laurel sobre el ácaro Varroa destructor Anderson y Trueman (Acari: Varroidae). Agric. Téc. (Chile) 64:238-244.
Nordström, S. 2003. Distribution of deformed wing virus within honey bee (Apis mellifera) brood cells infested with the ectoparasitic mite Varroa destructor. Exp. Appl. Acarol. 29:293-302.

Pérez, G., G. Otero, D. Mota, M. Ramírez, and R. Vandame. 2000. Comparing effects of three acaricides on Varroa jacobsoni (Acari: Varroidae) and Apis mellifera (Hymenoptera: Apidae) using two application techniques. Fla. Entomol. 83:468-476.

Rodríguez, M., M. Gerding, y A. France. 2006. Selección de aislamientos de hongos entomopatógenos para el control de huevos de la polilla del tomate, Tuta absoluta Meyrick (Lepidoptera: Gelechiidae). Agric. Téc. (Chile) 66:151-158.

Rodríguez, M., M. Gerding, and A. France. 2009. Selection of entomopathogenic fungi to control Varroa destructor (Acari: Varroidae). Chilean J. Agric. Res. 69:534-540.

SAG. 2002. Acciones sanitarias de prospección, control y vigilancia como bases para un programa de estrategias de manejo integrado de enfermedades en abejas, para incrementar la producción de la miel en la región de La Araucanía y de Los Lagos. p. 7-8. Proyecto fondo SAG $\mathrm{N}^{0}$ 71. Informe Técnico Final. Apicoop Ltda. Chile.

Tanada, Y., and H. Kaya. 1993. Fungal infections. p. 318366. In Tanada, Y., and H. Kaya (eds.) Insect pathology. Academic Press, San Diego, California, USA.

Wekesa, V.W., M. Nguya, M. Knapp, and H. Boga. 2005. Pathogenicity of Beauveria bassiana and Metarhizium anisopliae to the tobacco spider mite Tetranychus evansi. Exp. Appl. Acarol. 36:41-50. 